\title{
Corrosion behavior of stainless steel in chloride-contaminated
}

\section{carbonated concrete}

\author{
Federica Lollini, ${ }^{1 *}$ Maddalena Carsana, ${ }^{1}$ Matteo Gastaldi, ${ }^{1}$ and Elena Redaelli ${ }^{1}$ \\ ${ }^{1}$ Department of Chemistry, Materials and Chemical Engineering “Giulio Natta”, Politecnico di \\ Milano, Piazza Leonardo da Vinci 32, 20133 Milan, Italy \\ *corresponding author: federica.lollini@polimi.it
}

\begin{abstract}
The use of chloride-contaminated raw materials can minimize the consumption of natural resources, e.g. fresh water and virgin rocks, in the production of concrete to increase the sustainability of the construction sector. However, the possible benefits in terms of improved sustainability of concrete can only be evaluated on the long term, considering the durability (i.e., concrete's ability to guarantee an adequate service life when exposed in operating conditions). In this research, the use of stainless steel reinforcement in combination with chloride-contaminated concrete has been studied to construct durable and sustainable concrete infrastructures. Preliminary results showed that both austenitic, i.e. 304L and XM-28, and duplex, i.e. 23-04 and 22-05, stainless steels are suitable to be used in concrete made with chloride-contaminated raw materials and exposed to different environmental conditions, without chlorides penetration. However, when stainless steel bars are embedded in carbonated concrete their corrosion resistance might be impaired. This paper compares the corrosion behavior of the different stainless steels, two austenitic (304L and XM-28) and two duplex (23-04 and 22-05), embedded in alkaline and carbonated concrete and exposed to different controlled environmental conditions, to simulate aggressive environments. Results showed that 304L, 23-04 and 22-05 stainless steels are suitable
\end{abstract}


to be used also in concrete contaminated by chlorides even after carbonation and in the harshest exposure conditions. Conversely, corrosion might initiate on XM-28 when exposed to the most aggressive exposure conditions.

\section{Keywords}

Carbonation, stainless steel, chloride-contaminated concrete, corrosion, natural exposure, temperature cycles, humidity cycles.

\section{Introduction}

Concrete is the most widely used construction material in the world due to its relatively low cost, excellent strength properties and easy availability of its ingredients. However, its production leads to a considerable environmental impact, due to the huge consumption of natural resources, as, for instance, fresh water for the casting as well as the curing and virgin rocks for aggregates and Portland cement production. ${ }^{1}$ To reduce this impact, a sustainable option is the use of chloride-contaminated raw materials, such as seawater and salt-contaminated recycled aggregate as a portion of total aggregate. However, according to international codes and standards for reinforced concrete structures the chloride content from all raw materials should not exceed certain limits, due to the risk of corrosion of conventional carbon steel reinforcement. For instance the EN 206: 2016 limits the total chloride-ion content in reinforced concrete, for the chloride content class $\mathrm{Cl} 0.20$, to $0.2 \%$ by mass of cement. ${ }^{2}$ In fact, it is well known that chlorides above a certain threshold may locally destroy the passivity film present on carbon steel rebars embedded in concrete, thus enabling pitting corrosion.

Several studies have been carried out to evaluate the corrosion behavior of carbon steel in 
concrete made with seawater, both natural and artificial, and exposed to the further chloride penetration, whilst few researches have considered the employment of other raw materials contaminated by chlorides, as for instance salt-contaminated recycled aggregates or sea sand. Even less studies have concerned their use in combination with non-conventional reinforcement, as stainless steel, GFRP or epoxy-coated bars, or in exposure conditions where the further chloride penetration does not occur, as for structures far from the sea coasts. The majority of the available studies confirmed the unsuitability of seawater, ${ }^{3-8}$ recycled aggregates contaminated by chlorides ${ }^{9}$ and sea sand ${ }^{8: 10-11}$ in the concrete production since they make the carbon steel reinforcement highly vulnerable to corrosion. However, the results by Melchers and Chaves ${ }^{12}$ showed that even after 10 years of exposure in fog-room conditions little or no serious reinforcement corrosion was present on concretes made with seawater. Nishida et al. ${ }^{13}$ found that the introduction of blastfurnace slag might contribute significantly to the corrosion resistance of steel bars. The use of corrosion resistant reinforcement allows addressing the durability problem of reinforced concrete structures made with seawater and/or sea sand as raw materials. As a matter of fact it has been shown that the chloride content in seawater or sea-sand has little effect on the performance of FRP composites, ${ }^{6 ; 14-16}$ although lower performances were observed on basalt FRP especially at high temperatures $^{16-18}$. Also the behavior of epoxy-coated steel (in absence of defects of the coating) is not affected by the presence of chloride, ${ }^{8}$ and in seawater chloride amount is much lower than the critical chloride threshold of the traditional stainless steel reinforcement. ${ }^{19}$

To encourage the use of seawater as well as other raw materials contaminated by chlorides in reinforced concrete, the possible benefits in terms of improved sustainability of concrete can only be evaluated on the long term, considering the durability, i.e. the concrete's ability to guarantee an adequate service life, when exposed in operating conditions. Within the SeaCon 
project "Sustainable concrete using seawater, salt-contaminated aggregates, and non-corrosive reinforcement”, financed by the Infravation program, the use of stainless steel reinforcement in combination with chloride-contaminated concrete was studied to construct durable and sustainable concrete infrastructures. Corrosion tests were made on concrete specimens, made with chloridecontaminated raw materials and reinforced with austenitic, i.e. 304L and XM-28, and duplex, i.e. 23-04 and 22-05, stainless steels and for comparison carbon steel, exposed outdoor in an unsheltered environment and to cycles of temperature and humidity, without any further penetration of chlorides. Preliminary results showed that all the stainless steels employed in this study were suitable to be used in alkaline concretes, even when the specimens were exposed to the harshest environmental conditions (e.g. temperature higher than $38^{\circ} \mathrm{C}$ and in submerged conditions). ${ }^{20}$ However, in time, due to the outdoor exposure, carbonation can penetrate into the concrete, reaching the bars depth and the corrosion behavior of stainless steel might change. This paper focuses on the results of tests carried out on alkaline and carbonated concrete specimens exposed to different controlled environmental conditions, to simulate several aggressive environments, as well as natural unsheltered exposure conditions and compares the corrosion behavior of the different stainless steels embedded in alkaline and carbonated concrete.

\section{Materials and Methods}

Reinforced concrete specimens were manufactured using the concrete mixes reported in Table 1. A limestone Portland cement, type CEM II/A-LL 42.5R (according to European standard EN 197), carbon fly ash, fresh (de-ionized) water and natural aggregate, in particular two siliceous sands (0$2 \mathrm{~mm}$ and 0-4 $\mathrm{mm}$ ) and one gravel (4-12.5 mm), were used as reference raw materials to cast the reference mix (Ref) with virgin ingredients (without chlorides). Four chloride-contaminated 
concretes with different nominal chloride contents, ranging from 0.23 to $1.1 \%$ by mass of cement, were made by replacing the virgin materials with chloride-contaminated raw materials. In particular, in the mixes Cem and Cem-FA (the latter made with a higher amount of carbon fly ash) a cement contaminated with chlorides produced by Buzzi Unicem (SeaCon cement), with a composition similar to that of CEM II/A-LL 42.5R, but with the ground limestone replaced by a process dust (containing higher amount of chlorides compared to cement) was used. The Sea mix was obtained by replacing fresh water with seawater collected from the Mediterranean sea (Liguria - Italy). Finally, in the RCA mix, part of the natural gravel was replaced with recycled concrete aggregate (RCA), obtained by crushing and sieving old chloride-contaminated concrete specimens stored from previous researches made with Portland cement, w/c ratio of 0.5, crushed limestone aggregate and chloride contamination ranging from $1 \%$ to $5 \%$ by mass of cement.

All the mixes had a water/cement ratio, $w / c$, of 0.52 , obtained by mixing $335 \mathrm{~kg} / \mathrm{m}^{3}$ of cement (reference or SeaCon cement), $175 \mathrm{~kg} / \mathrm{m}^{3}$ of water (fresh water or seawater) and $30 \mathrm{~kg} / \mathrm{m}^{3}$ of carbon fly ash (80 kg/m³ for Cem-FA). $1824 \mathrm{~kg} / \mathrm{m}^{3}$ of siliceous aggregate was employed for mixes Ref, Cem and Sea; $1763 \mathrm{~kg} / \mathrm{m}^{3}$ of siliceous aggregate was employed for mix Cem-FA and, finally, 1437 $\mathrm{kg} / \mathrm{m}^{3}$ of siliceous aggregate and $365 \mathrm{~kg} / \mathrm{m}^{3}$ of RCA aggregate were utilized for mix RCA. An acrylic-based superplasticizer was added in order to achieve a class of consistence S4, which corresponds to a slump of the Abram's cone between 160 and $210 \mathrm{~mm}$. Table 1 shows the mix proportions of the concretes, the results of the slump test, the initial chlorides and the compressive strength after 7 and 28 days of moist curing. A target of $40 \mathrm{MPa}$ and $50 \mathrm{MPa}$ was achieved in terms of compressive strength after respectively 7 and 28 days of moist curing. Further details on composition and mechanical properties of the mixes can be found in Carsana et al. ${ }^{21}$

As reinforcement, besides 16-mm carbon steel rebars, on the basis of the results obtained in 
previous experimental works as well as literature research, ${ }^{22-25} 16-\mathrm{mm}$ bars of stainless steel of grades 304L, 22-05, 23-04 and 20-mm bars of XM-28 were used. All bars were reinforcing bars for reinforced concrete structures (ribbed) and their mechanical properties and chemical compositions are shown in Tables 2 and 3. The stainless steel bars were subjected to commercial sand blasting and pickling, in order to remove the oxide scale produced during hot forming (that affects the corrosion resistance of stainless steel bars $^{26,27}$ ), whilst carbon steel bars were subjected to sand blasting in the laboratory. Before testing, all the reinforcement were degreased with acetone and the two ends of each bar were masked with a styrene-butadiene-modified cement mortar and coated with a self-amalgamating tape; a length of the bar of $80 \mathrm{~mm}$ was exposed to the concrete. A 250 by 120 by $50 \mathrm{~mm}^{3}$ prism specimen reinforced with one bar of each type of steel with a concrete cover thickness of $15 \mathrm{~mm}$ was cast (fig. 1). Specimens were equipped with titanium wires (as internal reference electrode) along the bars and a titanium mesh (as counter electrode) at the bottom for electrochemical measurements. Three specimens were made for each mix.

After casting, reinforced specimens were cured in moist conditions for 7 days. After curing, the specimens were exposed in an unsheltered environment in Milan where no further penetration of chlorides occurred in order to simulate a structure made with chloride-contaminated raw materials exposed far from the sea and the marine aerosol. The three specimens of each mix were exposed outside for a different period: one specimen was exposed for about 4-6 months, another for 7-8 months and the third one for approximately 1 year. Afterward the specimens were exposed to controlled cycles of temperature and humidity in order to study the corrosion behavior of carbon and stainless steel bars in different environmental exposure conditions. In particular, to simulate temperate and tropical environments, the following exposure conditions of temperature $(\mathrm{T})$ and humidity $(\mathrm{H})$ were imposed for $2-4$ weeks until stable conditions were reached: $\mathrm{T}=20^{\circ} \mathrm{C} / \mathrm{H}=$ 
$50 \%$ (indoor exposure), $\mathrm{T}=20^{\circ} \mathrm{C} / \mathrm{H}=$ submerged, $\mathrm{T}=38^{\circ} \mathrm{C} / \mathrm{H}=100 \%, \mathrm{~T}=50^{\circ} \mathrm{C} / \mathrm{H}=$ submerged. Before the exposure to the controlled cycles, one specimen for each mix (in particular the one which was exposed outside for the shortest period) was exposed in a carbonation chamber until it was fully carbonated (carbonation was verified by means of periodic phenolphthalein tests on dust drilled from the specimens).

During the exposure period, the corrosion behavior of steel was monitored by means of electrochemical measurements of half-cell potential of steel ( $\left.E_{\text {corr }}\right)$ versus a saturated calomel electrode (SCE), placed on the specimen surface in the central part of each bar, and corrosion current density, measured through linear polarization resistance measurements $\left(\mathrm{R}_{\mathrm{p}}\right)$ as: $\mathrm{i}_{\text {corr }}=$ $\mathrm{B} /\left(\mathrm{R}_{\mathrm{p}}\right)$, where $\mathrm{B}$ was assumed equal to $26 \mathrm{mV}$.

At the end of the cycles, one series of alkaline specimens was split to extract the bars and the steel surface was visually observed.

\section{Results and Discussion}

After casting, monitoring of corrosion potential $\left(\mathrm{E}_{\text {corr }}\right)$ and corrosion current density ( $\left.\mathrm{i}_{\text {corr }}\right)$ of the bars started. Figures 2 and 3 depict, as examples, the time evolution of the corrosion potential and the corrosion current density of carbon steel and stainless steel of grade 304L, respectively, embedded in the alkaline concretes (only results on one specimen are reported) exposed initially to an unsheltered environment and then to the cycles of temperature and humidity (results on the other alkaline specimen were similar). In the figure symbols indicate the type of concrete. The starting date of the exposure was shifted in order to have the same ending point, to compare measurements taken in the same day and to account for possible variations of the corrosion parameters due to variation of exposure conditions. 
In Figure $2 A$ it can be observed that, after casting, the corrosion potential of carbon steel embedded in Ref, Cem, RCA and Cem-FA concretes was between -300 and -200 mV vs. SCE, and after about 28 days it approached values between -185 and $-120 \mathrm{mV}$ vs. SCE, indicating that the passivation layer was formed. On the carbon steel bars embedded in the Sea mixture, Ecorr initially around $500 \mathrm{mV}$ vs. SCE was measured, which increased in time, still remaining lower than $-200 \mathrm{mV}$ vs. SCE. A further increase of the potential was observed on all the carbon steel bars in the first months of outside exposure, indicating a reduction of the humidity of the concretes; then, during the outside exposure, stable conditions, even if with some fluctuations due to weather variations, were reached. These fluctuations were also observed on the bars employed in the demo project which were monitored with a data logger. ${ }^{28}$ After casting, corrosion rates even of the order of $5 \mathrm{~mA} / \mathrm{m}^{2}$ were measured on the carbon bars; these values however decreased in time and average corrosion current densities lower than $1 \mathrm{~mA} / \mathrm{m}^{2}$ were obtained on the bars in Ref, Cem, RCA and Cem-FA concretes. Carbon steel bars in the Sea mix showed average corrosion current densities in outside exposure slightly higher, around $1 \mathrm{~mA} / \mathrm{m}^{2}$ (fig. $2 B$ ).

As far as the corrosion behavior of carbon steel bars exposed to cycles of temperature and humidity is concerned, it can be observed that, during the exposure to $\mathrm{T}=20^{\circ} \mathrm{C} / \mathrm{H}=$ submerged, a decrease of the potential was observed on the carbon steel embedded in the Sea concrete, which approached values around $-250 \mathrm{mV}$ vs. SCE, although a significant increase of the corrosion current density was not observed (fig. $2 A$ and $2 B$ ). Carbon steel embedded in the Sea concrete experienced a significant decrease of the corrosion potential and a significant increase of the corrosion current density when exposed to temperatures of $38^{\circ} \mathrm{C}$ and $50^{\circ} \mathrm{C}$ and submerged. Carbon steel bars embedded in Ref, Cem, RCA and Cem-FA concretes when exposed to the different exposure cycles decreased the corrosion potential to values around -200 mV vs. SCE, but corrosion current 
density lower than $1 \mathrm{~mA} / \mathrm{m}^{2}$ was always measured (on RCA specimen $E_{\text {corr }}$ dropped even to values around $-300 \mathrm{mV}$ vs. SCE, but then it increased and reached stable conditions).

As far as the stainless steel of grade 304L is concerned, in Figure 3 a progressive increase of $E_{\text {corr }}$ (fig. $3 A$ ) and a decrease of $i_{\text {corr }}$ (fig. $3 B$ ) in the first 28 days of natural exposure can be observed, suggesting a modification of the passivity film of the reinforcement; on this steel a corrosion current density lower than $1 \mathrm{~mA} / \mathrm{m}^{2}$ was always detected also during the curing period (due to the presence of the passive film on stainless steel also before the contact with the alkalinity of the concrete). In the following months, a further increase of the potential, due to the drying of the specimens, was reached; then only slight fluctuations due to climatic variations were observed. No significant differences of $E_{\text {corr }}$ and $i_{\text {corr }}$ were noted on the bars embedded in the different types of concrete. In particular, at the end of the outdoor unsheltered exposure $E_{\text {corr }}$ was around $50 \mathrm{mV}$ vs. SCE, whilst $\mathrm{i}_{\text {corr }}$ was around $0.2 \mathrm{~mA} / \mathrm{m}^{2}$. These values indicate the passivity of the bars. The exposure to $20^{\circ} \mathrm{C}$ and relative humidity of $50 \%$ led to a slight increase of the potential, due to the further drying of the specimens, whilst during the immersion at $20^{\circ} \mathrm{C}$ and the exposure to $38^{\circ} \mathrm{C}$ and $50^{\circ} \mathrm{C}$, the potential decreased to values lower than those reached at the end of the outside exposure, which however could not be related to the initiation of corrosion, but to a variation of concrete humidity.

Figures 4-8 summarize the average values and the range of variability of corrosion potential and corrosion current density measured on all the bars, i.e. carbon steel and the different grades of stainless steel bars, embedded in the different concrete mixes, both alkaline and carbonated, and exposed to the different environmental conditions. The average values of corrosion potential and corrosion current density were calculated neglecting the transient period and the variability was evaluated considering the maximum and minimum values reached in each exposure condition in 
the specimens with the same mix. In the figures, the mixes and the exposure conditions are ordered in terms of increasing amount of expected chlorides and for increasing aggressiveness, respectively.

For carbon steel bars embedded in alkaline concretes (fig. 4) the average values of $E_{\text {corr }}$ and $i_{\text {corr }}$ measured outdoor were intermediate between the values measured during the cycles at $\mathrm{T}=20^{\circ} \mathrm{C} /$ $\mathrm{H}=50 \%$ and $\mathrm{T}=20^{\circ} \mathrm{C} / \mathrm{H}=$ submerged respectively and were similar among the different concretes ( $E_{\text {corr }}$ and $i_{\text {corr }}$ respectively around $-50 \mathrm{mV}$ vs. SCE and $0.6 \mathrm{~mA} / \mathrm{m}^{2}$ were measured when specimens were exposed outside); nevertheless in all the concretes a corrosion current density lower than 1-2 mA/m² was measured. This can suggest that no corrosion initiation occurred on the steel reinforcement. During the exposure cycles at temperatures of $38^{\circ} \mathrm{C}$ and $50^{\circ} \mathrm{C}$ a decrease of the corrosion potential and an increase of the corrosion current density were observed in the bars embedded in all types of concrete in comparison to those observed at $20^{\circ} \mathrm{C}$. Corrosion potential around -200 mV vs. SCE and corrosion current density lower than $1 \mathrm{~mA} / \mathrm{m}^{2}$ were evaluated on the bars embedded in Ref, Cem, Cem-FA and RCA concretes, with negligible differences among these concretes, in both exposure conditions. More significant changes were noted for carbon steel bars embedded in concrete made with seawater. As a matter of fact, corrosion potential dropped to values lower than $-400 \mathrm{mV}$ vs. SCE and corrosion current density increase to values higher than $2.5 \mathrm{~mA} / \mathrm{m}^{2}$, clearly indicating that the higher environmental aggressiveness led to the initiation of corrosion. No sign of corrosion was visually observed at the end of the exposure cycles, after splitting the specimens, on the carbon steel bars embedded in the Ref, Cem, Cem-FA and RCA concretes; conversely pits, in proximity of the masked parts of the bars, were observed on the bars embedded in the Sea concrete, confirming the initiation of corrosion (fig. 9A).

In carbonated concrete, during the indoor exposure, $E_{\text {corr }}$ was higher than $-150 \mathrm{mV}$ vs. SCE and in 
the Ref concrete it was higher than that measured in the alkaline concrete. In carbonated concrete, although bars were no more protected by the passive layer, due to the carbonation of concrete cover, lower $\mathrm{i}_{\text {corr }}$ was measured, since concrete is more resistive. ${ }^{29}$ When specimens were immersed in water, $\mathrm{E}_{\text {corr }}$ of all carbon steel bars embedded in all the concretes experienced a significant drop, reaching values around $-600 \mathrm{mV}$ vs. SCE, clearly indicating that, in carbonated concrete, corrosion propagated. In the Ref concrete, $\mathrm{i}_{\text {corr }}$ higher than $10 \mathrm{~mA} / \mathrm{m}^{2}$ was measured, whilst in concretes made with chloride-contaminated raw materials, $\dot{i}_{\text {corr }}$ even higher than 70 $\mathrm{mA} / \mathrm{m}^{2}$ and increasing the chloride content in the raw materials, were measured, confirming that, even a low amount of chlorides led to a significant increase of the corrosion rate (fig. 10).

As far as the stainless steel bars of grade 304L embedded in alkaline concretes are concerned (fig. 5), the corrosion potential was similar for all bars when they were embedded in the different mixes and exposed to different conditions, confirming that this type of reinforcement is not affected by the low amount of chloride present in the raw materials. A decrease of the corrosion potential was observed when specimens were exposed to temperatures of $38^{\circ} \mathrm{C}$ and $50^{\circ} \mathrm{C}$, however in all the bars, even those embedded in concretes made with seawater, values higher than -200 mV vs. SCE were measured. The corrosion current density of the bars was comparable in all the types of concrete exposed to the different cycles, and around $0.5 \mathrm{~mA} / \mathrm{m}^{2}$, suggesting that passive conditions were maintained even when the bars were exposed to the harshest environmental conditions. This is in agreement with the results of Gastaldi and Bertolini ${ }^{22}$ where 304L bars were embedded in concrete with mixed-in chloride up to $8 \%$ and corrosion did not occur even when specimens were exposed to $60^{\circ} \mathrm{C}$. The visual observation of the bar, after the exposure to the cycles confirmed the absence of any sign of corrosion (fig. 9B). In the carbonated concretes, in all the exposure conditions, $\mathrm{E}_{\text {corr }}$ and $\mathrm{i}_{\text {corr }}$ values were similar to those measured in alkaline concretes, suggesting 
that passive conditions were also maintained even in the more aggressive environmental conditions. Other studies showed the suitability of 304L stainless steel even in carbonated concrete containing more than $4 \%$ chlorides by mass of cement when exposed to $20^{\circ} \mathrm{C}^{27}$

The duplex stainless steel bars of grades 22-05 and 23-04 showed a similar corrosion behaviour (figs. 6 and 7). Corrosion potential higher than $-100 \mathrm{mV}$ vs. SCE was measured in the different types of alkaline concrete, even when immersed at $50^{\circ} \mathrm{C}$. Although corrosion rate was, in all exposure conditions, of the order of $2-4 \mathrm{~mA} / \mathrm{m}^{2}$, it did not indicate the onset of corrosion, since these values were also measured on the bars embedded in the Ref concretes, without chlorides. Also these stainless steel bars did not show any sign of onset of corrosion, as confirmed by the visual observation even in the Sea concrete exposed to the most aggressive exposure cycles. The corrosion behaviour of stainless steel of grades 22-05 and 23-04 embedded in the carbonated concretes was similar to those in the alkaline concretes, indicating that these bars did not experience the initiation of corrosion with these chloride contents also when carbonation reach the reinforcement, as also stated in Bertolini et al. ${ }^{27}$

The stainless steel of grade XM-28 showed similar corrosion behavior in all alkaline concretes and environments (fig. 8). Corrosion potential higher than $-150 \mathrm{mV}$ vs. SCE and corrosion current density lower than $1 \mathrm{~mA} / \mathrm{m}^{2}$ were measured even in the most aggressive environment conditions (i.e. $\mathrm{T}=38^{\circ} \mathrm{C}$ and $50^{\circ} \mathrm{C}$ ). Beside the reference concrete, no significant difference in terms of corrosion behavior can be observed between the alkaline and carbonated concretes made with the contaminated cement (i.e. Cem and Cem-FA mixes) in all the exposure conditions. In the RCA concretes, a variation of the corrosion behavior of XM-28 can be observed when the concrete is carbonated and exposed to the most aggressive conditions, i.e. immersed at temperatures of $20^{\circ} \mathrm{C}$, $38^{\circ} \mathrm{C}$ and $50^{\circ} \mathrm{C}$. As a matter of fact corrosion potentials around $-300 \mathrm{mV}$ vs. SCE were measured. 
These values might indicate the initiation of corrosion; however the corrosion current densities were lower than $1 \mathrm{~mA} / \mathrm{m}^{2}$. Even in the Sea concrete, according to the measurement of corrosion potential, the corrosion behavior seemed to change when specimens were carbonated and exposed to the higher temperature; however also in this case corrosion current density did not clearly confirm the behavior. It should be underlined that each exposure condition was maintained only for 2-3 weeks and, although stable values of corrosion potential and corrosion current density were reached at the end of the different exposure periods, the prolonged exposure in the harshest environment might lead to a clear initiation of corrosion.

In order to detect the suitable combinations between type of bar and type of concrete that, in absence of any further chlorides penetration, would allow to guarantee the durability requirements, in the different environmental exposures considered in this work, Figure 11 shows the relationship between the corrosion potential and the corrosion current density as a function of the type of mix and the exposure condition. A combination can be considered suitable when the corrosion potential is higher than $-250 \mathrm{mV}$ vs. SCE and the corrosion current density is lower than $1-2 \mathrm{~mA} / \mathrm{m}^{2}$ (for duplex stainless steel bars, since in each exposure condition high corrosion current densities were measured, this last criteria was neglected).

Although carbon steel bars remained passive in alkaline concretes made with contaminated cement and recycled aggregates, when exposed both to the mildest exposure conditions, representative of temperate climate (temperatures around $20^{\circ} \mathrm{C}$ ), and to the most aggressive conditions, representative of tropical climate (temperatures higher than $38^{\circ} \mathrm{C}$ ), this type of bar showed to be unsuitable to be used in chloride-contaminated concretes exposed to the penetration of carbonation (fig. 11A). As a matter of fact, in carbonated concrete, carbon steel showed an increasing corrosion current density as a function of the chlorides content of the raw materials, confirming the risk of 
the presence of chlorides, even below the critical chloride threshold (i.e. the amount of chloride needed to break the passive film), when concrete is carbonated. The use of carbon steel bar in concrete made with seawater was inappropriate even in alkaline concrete exposed to the aggressive conditions.

As far as stainless steel bars are concerned, the grades 304L, 25-05 and 23-04 showed to be suitable to be used in combination with concretes made with chloride-contaminated raw materials in all the exposure conditions considered in the work, even those that simulated the tropical climates. As a matter of fact, also when concrete is carbonated, the initiation of corrosion did not occur in any exposure condition.

The stainless steel XM-28, which has a lower corrosion resistance in comparison to the others, due to its chemical composition (due to the presence of Manganese ${ }^{24,30}$ ), showed to be suitable in combination with concretes made with chloride-contaminated raw materials in all the exposure conditions considered in the work, even those which simulated the harshest environments, when the concrete is alkaline. Its corrosion behavior when embedded in carbonated concretes made with seawater as well as recycled aggregates, and exposed to the harshest conditions, was slightly different in comparison to that observed in the reference concrete without chlorides, suggesting a possible initiation of corrosion. Hence, its suitability in the most aggressive environments when the concrete is carbonated needs to be further assessed.

\section{Conclusions}

Corrosion tests, carried out on both alkaline and carbonated reinforced concrete specimens exposed to controlled cycles of temperature and humidity, without further chloride penetration, e.g. in structures far from the sea, were performed in order to evaluate the suitability of different 
stainless steel bars to be employed in chloride-contaminated concretes.

The use of chloride-contaminated raw materials for the production of concrete seems to be allowed in combination with stainless steel bars of grades 304L, 22-05 and 23-04, also when carbonation reaches the bars depth, since corrosion did not initiate on these types of stainless steel when exposed to the different environmental conditions, even those that simulated tropical climates ( $50^{\circ} \mathrm{C}$ and submerged specimen). Stainless steel of grade XM-28 was suitable in alkaline concrete made with chloride-contaminated raw materials, whilst it showed a possible initiation of corrosion when embedded in carbonated concrete made with recycled aggregates and seawater and exposed to the harshest conditions. Hence, once the concrete is carbonated, it seems to be suitable only in mild environment.

Carbon steel bars remained passive in alkaline concretes made with contaminated cement and recycled aggregates, whilst it corroded in concrete made with seawater and exposed to high temperature and humidity. In carbonated concrete, carbon steel showed an increasing corrosion current density as a function of the chlorides content of the raw materials, confirming the risk of the presence of chlorides, even below the critical chloride threshold, when concrete is carbonated.

\section{ACKNOWLEDGMENTS}

The project was made possible with the financial support received from the Infravation Program under Grant Agreement No. 31109806.005-SEACON. The opinions in this paper are those of the authors and not necessarily those of the sponsors or collaborators. The Authors are grateful to the partners who provided the materials (Buzzi Unicem and Valbruna).

\section{References}


[1] J. S. Damtoft, J. Lukasik, D. Herfort, D. Sorrentino, and E. M. Gartner, “Sustainable Development and Climate Change Initiatives,” Cement Concrete Res 38, no. 2 (February 2008): 115-127, https://doi.org/10.1016/j.cemconres.2007.09.008

[2] EN 206: 2016. Concrete. Specification, performance, production and conformity.

[3] S. K. Kaushik and S. Islam, "Suitability of Sea Water for Mixing Structural Concrete Exposed to a Marine Environment”, Cement Concrete Comp. 17 (1995): 177-185, https://doi.org/10.1016/0958-9465(95)00015-5

[4] T. U. Mohammed, H. Hamada, and T. Yamaji, "Performance of seawater-mixed concrete in the tidal environment”, Cement Concrete Res. 34, no. 4 (April 2004): 593-601, https://doi.org/10.1016/j.cemconres.2003.09.020

[5] R. Shalon and M. Rapheal, "Influence of Sea Water on Corrosion of Reinforcement”, ACI Journal Proceeding 55, no. 6, (June 1959): 1251-1268.

[6] J. Xiao, C. Qiang, A. Nanni, and K. Zhang, "Use of sea-sand and seawater in concrete construction: Current status and future opportunities”, Constr. Build. Mater. 155 (November 2017): 1101-1111. https://doi.org/10.1016/j.conbuildmat.2017.08.130

[7] E. T. Anacta, "Effect of Salt-Contaminated Mixing Water and Aggregates on Time-to-Initiate Rebar Corrosion in Concrete”, International Journal of Scientific \& Engineering Research 4, no. 4 (April 2013): 1524-1527.

[8] K. Katano, I. Y. Takeda, and K. Iriya, “Properties and Application of Concrete Made with Sea Water and Un-washed Sea Sand”, (paper presentation Third International Conference on Sustainable Construction Materials and Technologies, Kyoto, August 18-21, 2013).

[9] F. Debieb, L. Courard, S. Kenai, and R. Degeimbre, R., “Mechanical and durability properties of concrete using contaminated recycled aggregates”, Cement Concrete Comp. 32, no. 
6 (July 2010): 421-426, https://doi.org/10.1016/j.cemconcomp.2010.03.004

[10] W. P. S. Dias, G. A. P. S. N. Seneviratne, and S. M. A. Nanayakkara, “Offshore sand for reinforced concrete”, Constr. Build. Mater. 22, no. 7 (July 2008): 1377-1384, https://doi.org/10.1016/j.conbuildmat.2007.04.006

[11] D. A. R. Dolage, M. G. S. Dias, and C. T. Ariyawansa, “Offshore Sand as a Fine Aggregate for Concrete Production”, British Journal of Applied Science \& Technology 3, no. 4 (OctoberDecember 2013): 813-825.

[12] R. E. Melchers and I.A. Chaves, “A comparative study of chlorides and longer-term reinforcement corrosion”, Mater. Corros. 68, no. 6 (December 2017): 613-621, https://doi.org/10.1002/maco.201609310

[13] T. Nishida, N. Otsuki, H. Ohara, Z. M. Garba-Say, and T. Nagata, "Some Considerations for Applicability of Seawater as Mixing Water in Concrete”, J. Mater. Civ. Eng. 27, no. 7 (July 2015) Article number B4014004, https://doi.org/10.1061/(ASCE)MT.1943-5533.0001006 [14] M. Khatibmasjedi and A. Nanni, “Durability of GFRP reinforcement in Seacon” (oral presentation The Fifth International Conference on Durability of Fiber Reinforced Polymer (FRP) Composites for Construction and Rehabilitation of Structures, Sherbrooke, Quebec, CANADA, 2017).

[15] M. Khatibmasjedi, G. Claure, and A. Nanni, “Durability of GFRP reinforcement in seawater concrete - part I” (oral presentation, CAMX 2017 - The Composites and Advanced Materials Expo, Orlando, Florida, 2017).

[16] F. Guo, S. Al-Saadi, R. K. Singh Raman, and X. L. Zhao, "Durability of fiber reinforced polymer (FRP) in simulated seawater sea sand concrete (SWSSC) environment”, Corros. Sci. 141 (August 2018): 1-13, https://doi.org/10.1016/j.corsci.2018.06.022 
[17] Z. Dong, G. Wu, X.-L. Zhao, H. Zhu, and J. Lian, “Bond durability of steel-FRP composite bars embedded in seawater sea-sand concrete under constant bending and shearing stress”, Constr. Build. Mater. 192 (December 2018): 808-817, https://doi.org/10.1016/j.conbuildmat.2018.10.154

[18] Z. Dong, G. Wu, X-L. Zhao, H. Zhu, and J. Lian, “Durability test on the flexural performance of seawater sea-sand concrete beams completely reinforced with FRP bars”, Constr. Build. Mater. 192 (December 2018): 671-682, https://doi.org/10.1016/j.conbuildmat.2018.10.154 [19] N. Otsuki, A. K. Min, T. Nagata, and C. Yi, “Durability of Seawater Mixed Concrete with Different Replacement Ratio of BFS (Blast Furnace Slag) and FA (Fly Ash)”, Journal of Civil Engineering and Architecture 10 (May 2016): 568-580

[20] F. Lollini, M. Carsana, M. Gastaldi, E. Redaelli, F. Torabian Isfahani, and L. Bertolini, "Corrosion behaviour of reinforcement in concrete with chloride-contaminated raw materials Part I: laboratory tests”, Metallurgia Italiana 7-8 (July-August 2017): 39-42.

[21] M. Carsana, M. Gastaldi, F. Lollini, and E. Redaelli, “Durability-related properties of concrete made with chloride-contaminated materials”, ASTM Advances in Civil Engineering Materials (in review)

[22] M. Gastaldi and L. Bertolini, “Effect of temperature on the corrosion behaviour of lownickel duplex stainless steel bars in concrete”, Cement Concrete Res. 56 (February 2014): 52-60, https://doi.org/10.1016/j.cemconres.2013.11.004

[23] M. Gastaldi, F. Lollini, and L. Bertolini, “Performance-based durability design of reinforced concrete structures with stainless steel bars”, Metallurgia Italiana 7-8 (July-August 2014): 1720.

[24] L. Bertolini and M. Gastaldi, “Corrosion resistance of low-nickel duplex stainless steel 
rebars”, Mater. Corros. 62, no. 2 (January 2011): 120-129, https://doi.org/10.1002/maco.201005774

[25] F. Lollini, M. Carsana, M. Gastaldi, and E. Redaelli, “Corrosion behaviour of stainless steel reinforcement in concrete”, Corrosion Review (in press), https://doi.org/10.1515/correv-20170088

[26] U.Nurnberger, W.Beul, G.Onuseit, “Corrosion Behaviour of Welded Stainless Reinforcing Steel in Concrete”, Otto Graf Journal 4 (1993): 225-259.

[27] L. Bertolini, M. Gastaldi, P. Pedeferri, and E. Redaelli, "Factors influencing the corrosion resistance of austenitic and duplex stainless steel bars in chloride bearing concrete” (oral presentation, 15th International Corrosion Congress - ICC, Granada, 2002).

[28] E. Redaelli, A. Arrigoni, M. Carsana, G. Dotelli, F. Lollini, M. Gastaldi, M., F. Bertola, F. Canonico, and A. Nanni, “Culvert Prototype Made with Seawater Concrete: Materials Characterization, Monitoring and Environmental Impact, ASTM Advances in Civil Engineering Materials (in review)

[29] G. K. Glass, C. L. Page, and N. R. Short, "Factors affecting the corrosion rate of steel in carbonated mortars”, Corros. Sci. 32, no. 12 (1991): 1283-1294.

[30] A. Pardo, M. C. Merino, A. E. Coy, F. Viejo, R. Arrabal, and E. Matykina, "Pitting corrosion behaviour of austenitic stainless steels - combining effects of Mn and Mo additions”, Corros. Sci. 50, no. 6 (June 2008): 1796-1806, https://doi.org/10.1016/j.corsci.2008.04.005 
TABLE 1 Composition and properties of the five concrete mixes

\begin{tabular}{|c|c|c|c|c|c|}
\hline & Ref & Cem & Cem-FA & RCA & Sea \\
\hline Reference cement, $\mathrm{kg} / \mathrm{m}^{3}$ & 335 & - & - & 335 & 335 \\
\hline Seacon cement, $\mathrm{kg} / \mathrm{m}^{3}$ & - & 335 & 335 & - & - \\
\hline Fresh water, $\mathrm{kg} / \mathrm{m}^{3}$ & 175 & 175 & 175 & 175 & - \\
\hline Seawater, $\mathrm{kg} / \mathrm{m}^{3}$ & - & - & - & - & 175 \\
\hline Fly ash, kg/m $\mathrm{m}^{3}$ & 30 & 30 & 80 & 30 & 30 \\
\hline $0-2 \mathrm{~mm}$ sand, $\mathrm{kg} / \mathrm{m}^{3}$ & 490 & 490 & 473 & 484 & 490 \\
\hline $0-4 \mathrm{~mm}$ sand, $\mathrm{kg} / \mathrm{m}^{3}$ & 596 & 596 & 576 & 588 & 596 \\
\hline Gravel, kg/m $\mathrm{m}^{3}$ & 739 & 739 & 714 & 365 & 739 \\
\hline $\mathrm{RCA}, \mathrm{kg} / \mathrm{m}^{3}$ & - & - & - & 365 & - \\
\hline w/c ratio & 0.52 & 0.52 & 0.52 & 0.52 & 0.52 \\
\hline $\mathrm{w} / \mathrm{b}$ ratio & 0.48 & 0.48 & 0.42 & 0.48 & 0.48 \\
\hline Slump, mm & 200 & 185 & 210 & 200 & 185 \\
\hline Expected chlorides, \% by cement mass & 0.02 & 0.23 & 0.23 & 0.78 & 1.1 \\
\hline $\mathrm{f}_{\mathrm{c}, \text { cube, } 7 \text { days, }} \mathrm{MPa}$ & 41.5 & 45.3 & 50.0 & 45.7 & 44.4 \\
\hline $\mathrm{f}_{\mathrm{c}, \text { cube,28days, } \mathrm{MPa}}$ & 50.7 & 53.2 & 57.7 & 58.7 & 50.0 \\
\hline
\end{tabular}

TABLE 2 Mechanical properties (U.S. = ultimate strength; Y.S.0.2\% = yield strength at $0.2 \%$ of deformation; $\mathrm{Agt}=$ total elongation at maximum force) and main alloy elements of the stainless steel bars.

\begin{tabular}{|c|c|c|c|c|c|c|c|c|c|c|c|}
\hline \multirow{2}{*}{$\begin{array}{c}\text { Steel } \\
\text { name }\end{array}$} & \multicolumn{2}{|c|}{ Designation } & \multicolumn{3}{|c|}{$\begin{array}{l}\text { Mechanical } \\
\text { properties }\end{array}$} & \multicolumn{6}{|c|}{ Main alloy elements (\%) } \\
\hline & EN 10088-1 & UNS & $\begin{array}{l}\text { U.S., } \\
M P a\end{array}$ & $\begin{array}{c}Y . S .0 .2 \\
\% M P a\end{array}$ & $\begin{array}{l}\text { Agt } \\
(\%)\end{array}$ & $C$ & $\mathrm{Cr}$ & $\mathrm{Ni}$ & Mo & $M n$ & $N$ \\
\hline 304L & 1.4307 & S30403 & 760 & 543 & 24 & 0.021 & 18.51 & 8.61 & 0.15 & 1.31 & 0.146 \\
\hline $22-05$ & 1.4462 & S31803 & 838 & 607 & 24 & 0.021 & 22.56 & 5.26 & 3.332 & 1.48 & 0.158 \\
\hline 23-04 & 1.4362 & S32304 & 750 & 524 & 18 & 0.019 & 23.37 & 4.27 & 0.30 & 1.23 & 0.095 \\
\hline XM-28 & - & S24100 & 923 & 672 & - & 0.11 & 17.41 & 2.23 & 0.18 & 12.02 & 0.3 \\
\hline
\end{tabular}


TABLE 3 Mechanical properties (U.S. = ultimate strength; Y.S.0.2\% = yield strength at $0.2 \%$ of deformation; Agt = total elongation at maximum force) and main alloy elements of the carbon steel bars.

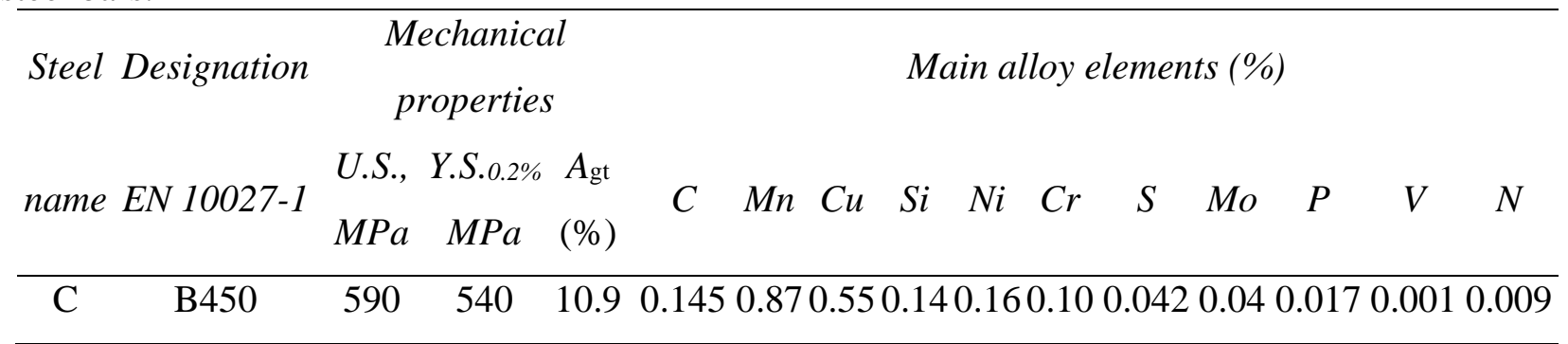

\section{List of Figure Captions}

a)


b)

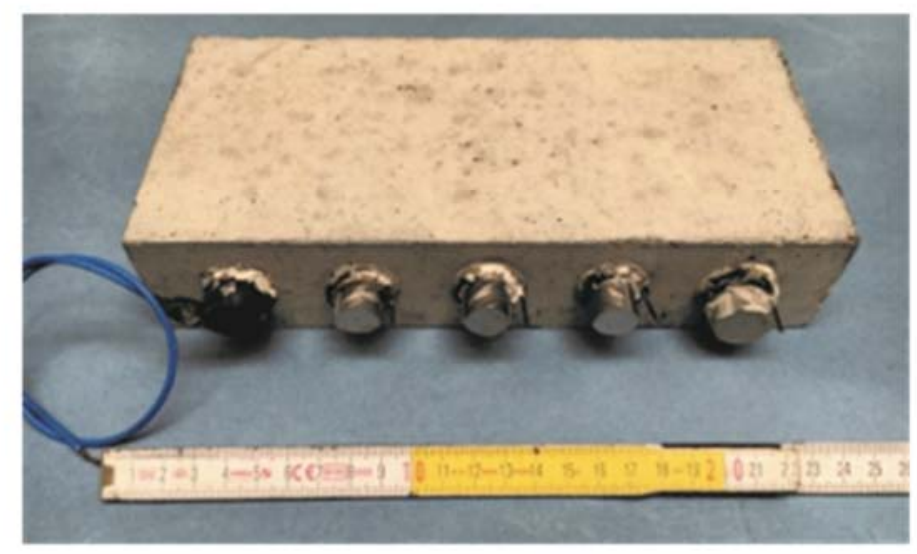

FIG. 1 Geometry $(A)$ and photo $(B)$ of reinforced specimen (dimensions in $\mathrm{mm}$ ). 

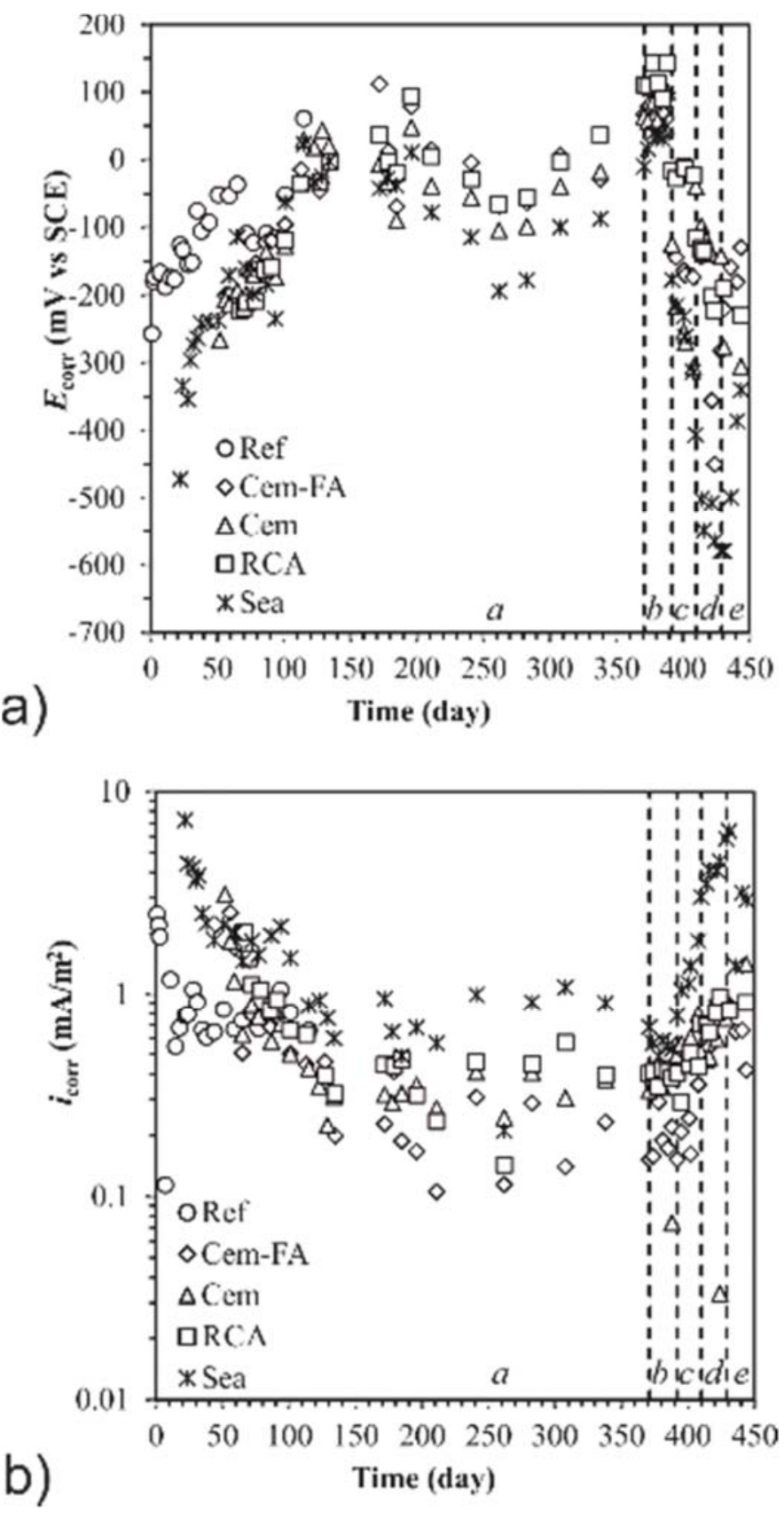

FIG. 2 Evolution in time of the corrosion potential $(A)$ and corrosion current density $(B)$ of carbon steel bars embedded in the different concretes exposed to different environmental conditions: unsheltered outdoor environment, $\mathrm{a} ; \mathrm{T}=20^{\circ} \mathrm{C} / \mathrm{H}=50 \%, \mathrm{~b} ; \mathrm{T}=20^{\circ} \mathrm{C} / \mathrm{H}=$ submerged, c; $\mathrm{T}=38^{\circ} \mathrm{C} / \mathrm{H}=100 \%, \mathrm{~d} ; \mathrm{T}=50^{\circ} \mathrm{C} / \mathrm{H}=$ submerged, e. 

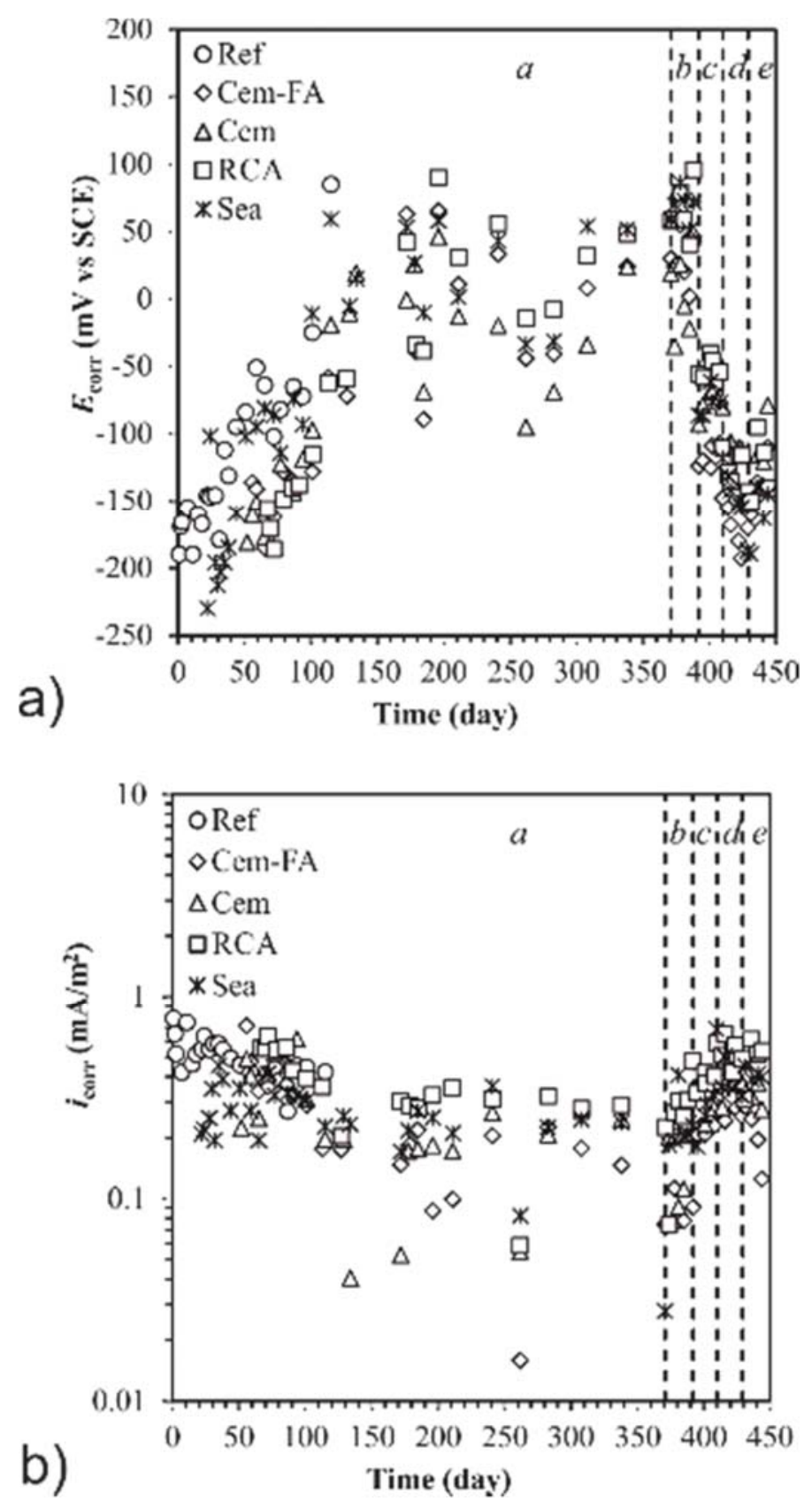

FIG. 3 Evolution in time of the corrosion potential $(A)$ and corrosion current density $(B)$ of stainless steel bars of grade 304L embedded in the different concretes exposed to different environment conditions: unsheltered outdoor environment, a; $\mathrm{T}=20^{\circ} \mathrm{C} / \mathrm{H}=50 \%, \mathrm{~b} ; \mathrm{T}=20^{\circ} \mathrm{C} / \mathrm{H}$ $=$ submerged, $\mathrm{c} ; \mathrm{T}=38^{\circ} \mathrm{C} / \mathrm{H}=100 \%, \mathrm{~d} ; \mathrm{T}=50^{\circ} \mathrm{C} / \mathrm{H}=$ submerged, e. 



FIG. 4 Average values and range of variability of corrosion potential $(A)$ and corrosion current density $(B)$ of carbon steel bars embedded in alkaline and carbonated concretes exposed to different exposure conditions (unsheltered outdoor environment, a; $\mathrm{T}=20^{\circ} \mathrm{C} / \mathrm{H}=50 \%$, b; $\mathrm{T}=$ $20^{\circ} \mathrm{C} / \mathrm{H}=$ submerged, c; $\mathrm{T}=38^{\circ} \mathrm{C} / \mathrm{H}=100 \%, \mathrm{~d} ; \mathrm{T}=50^{\circ} \mathrm{C} / \mathrm{H}=$ submerged, e). 



FIG. 5 Average values and range of variability of corrosion potential $(A)$ and corrosion current density $(B)$ of stainless steel bars of grade 304L embedded in alkaline and carbonated concretes exposed to different exposure conditions (unsheltered outdoor environment, a; $\mathrm{T}=20^{\circ} \mathrm{C} /$ $\mathrm{H}=50 \%, \mathrm{~b} ; \mathrm{T}=20^{\circ} \mathrm{C} / \mathrm{H}=$ submerged, $\mathrm{c} ; \mathrm{T}=38^{\circ} \mathrm{C} / \mathrm{H}=100 \%, \mathrm{~d} ; \mathrm{T}=50^{\circ} \mathrm{C} / \mathrm{H}=$ submerged, e). 

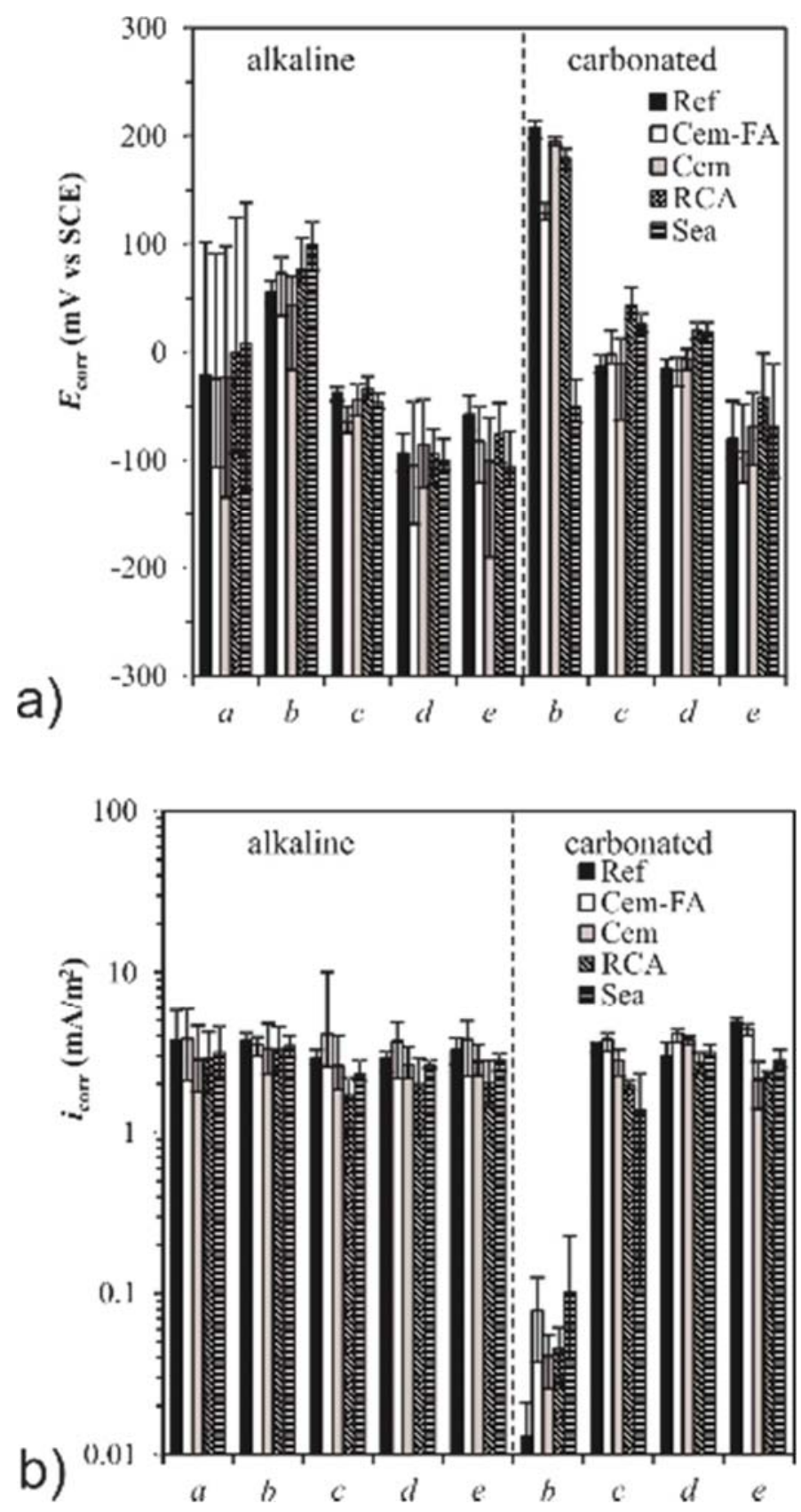

FIG. 6 Average values and range of variability of corrosion potential $(A)$ and corrosion current density (B) of stainless steel bars of grade 22-05 embedded in alkaline and carbonated concretes exposed to different exposure conditions (unsheltered outdoor environment, a; $\mathrm{T}=20^{\circ} \mathrm{C} /$ $\mathrm{H}=50 \%, \mathrm{~b} ; \mathrm{T}=20^{\circ} \mathrm{C} / \mathrm{H}=$ submerged, $\mathrm{c} ; \mathrm{T}=38^{\circ} \mathrm{C} / \mathrm{H}=100 \%, \mathrm{~d} ; \mathrm{T}=50^{\circ} \mathrm{C} / \mathrm{H}=$ submerged, e). 

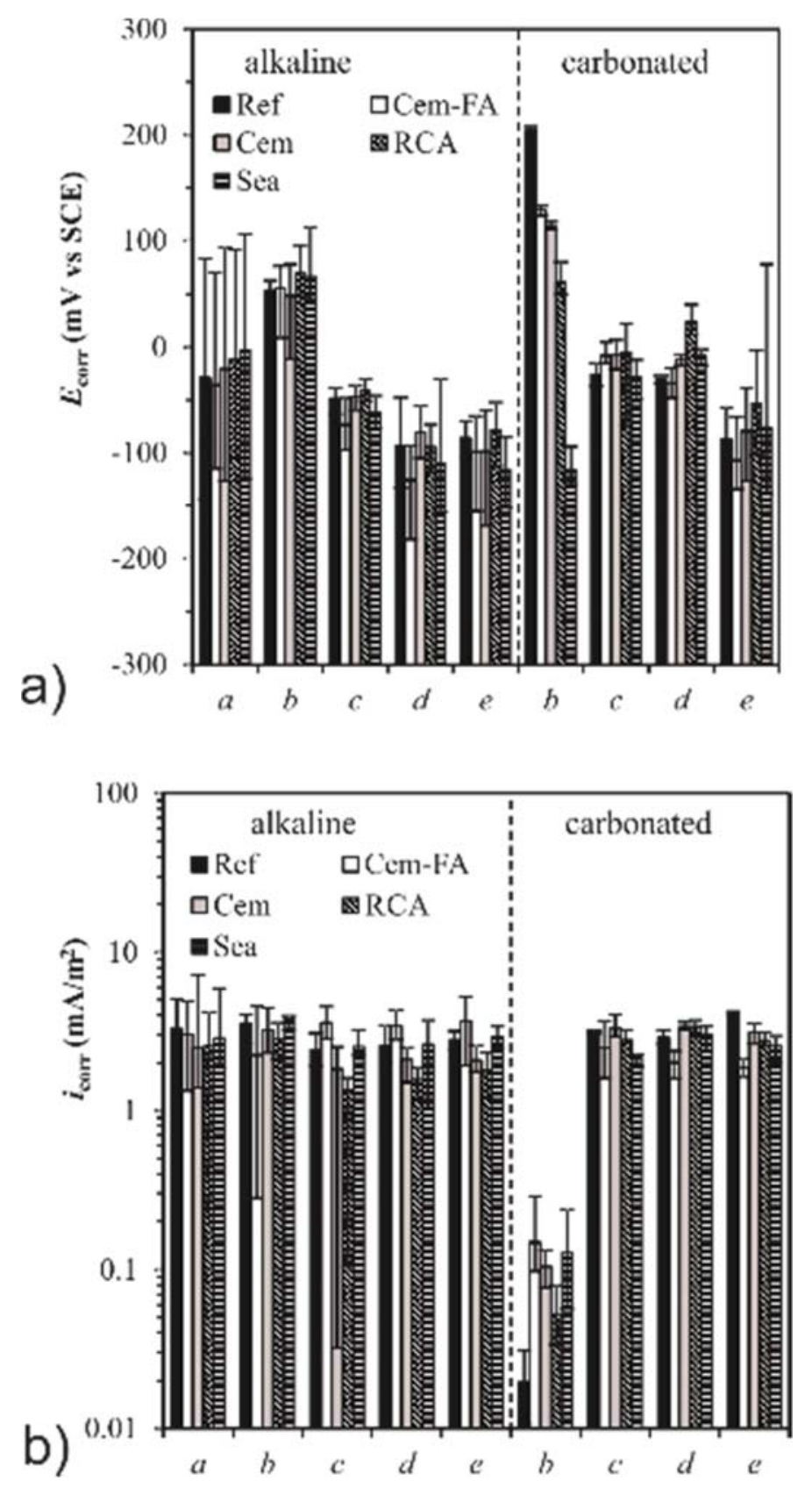

FIG. 7 Average values and range of variability of corrosion potential $(A)$ and corrosion current density $(B)$ of stainless steel bars of grade 23-04 embedded in alkaline and carbonated concretes exposed to different exposure conditions (unsheltered outdoor environment, a; $\mathrm{T}=20^{\circ} \mathrm{C}$ / $\mathrm{H}=50 \%, \mathrm{~b} ; \mathrm{T}=20^{\circ} \mathrm{C} / \mathrm{H}=$ submerged, $\mathrm{c} ; \mathrm{T}=38^{\circ} \mathrm{C} / \mathrm{H}=100 \%, \mathrm{~d} ; \mathrm{T}=50^{\circ} \mathrm{C} / \mathrm{H}=$ submerged, e). 

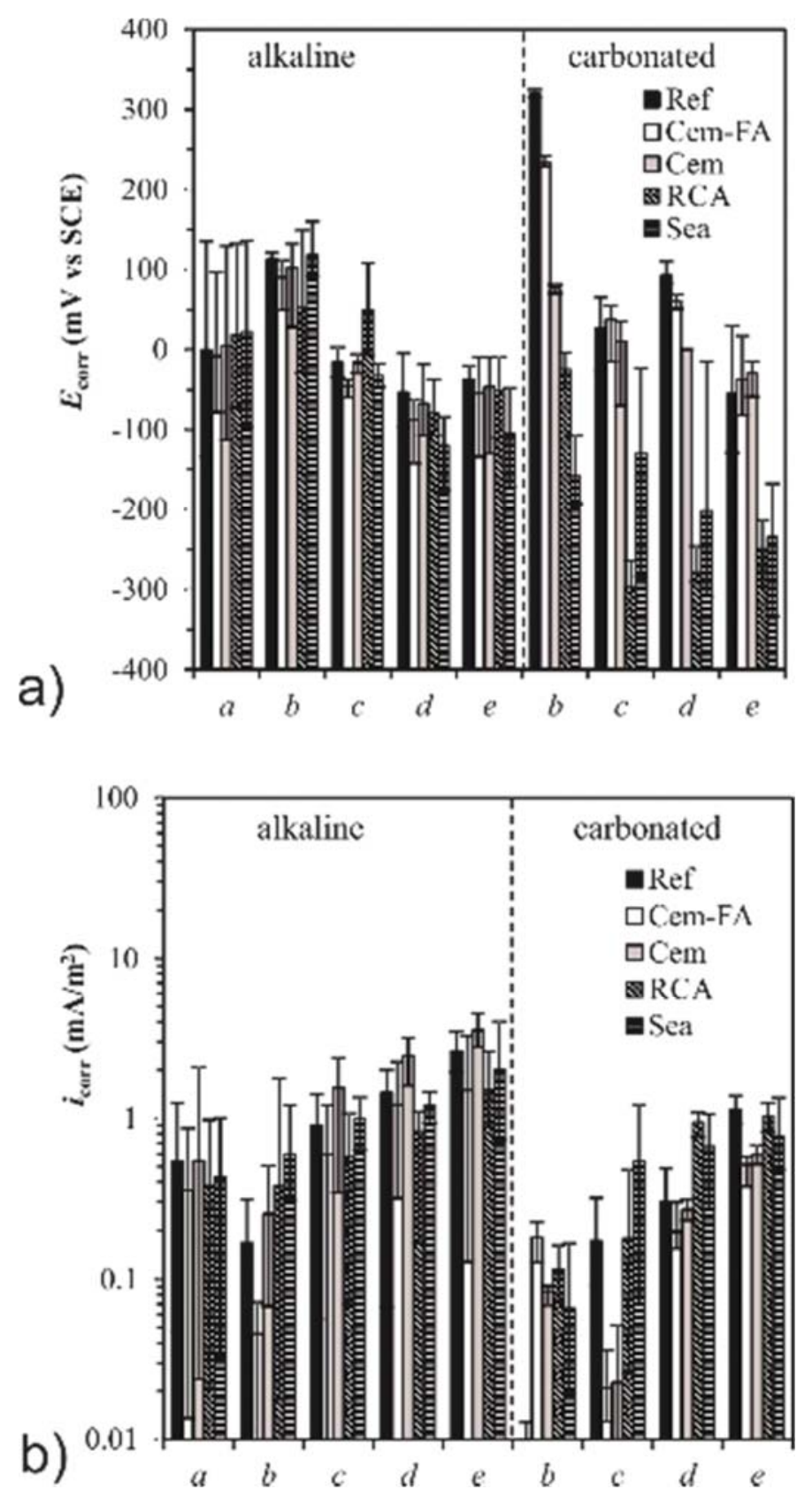

FIG. 8 Average values and range of variability of corrosion potential $(A)$ and corrosion current density $(B)$ of stainless steel bars of grade XM-28 embedded in alkaline and carbonated concretes exposed to different exposure conditions (unsheltered outdoor environment, a; $\mathrm{T}=20^{\circ} \mathrm{C} /$ $\mathrm{H}=50 \%, \mathrm{~b} ; \mathrm{T}=20^{\circ} \mathrm{C} / \mathrm{H}=$ submerged, $\mathrm{c} ; \mathrm{T}=38^{\circ} \mathrm{C} / \mathrm{H}=100 \%, \mathrm{~d} ; \mathrm{T}=50^{\circ} \mathrm{C} / \mathrm{H}=$ submerged, e). 
a)

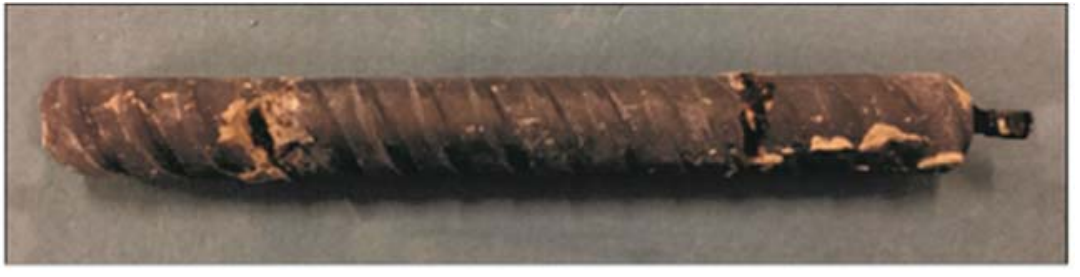

b)

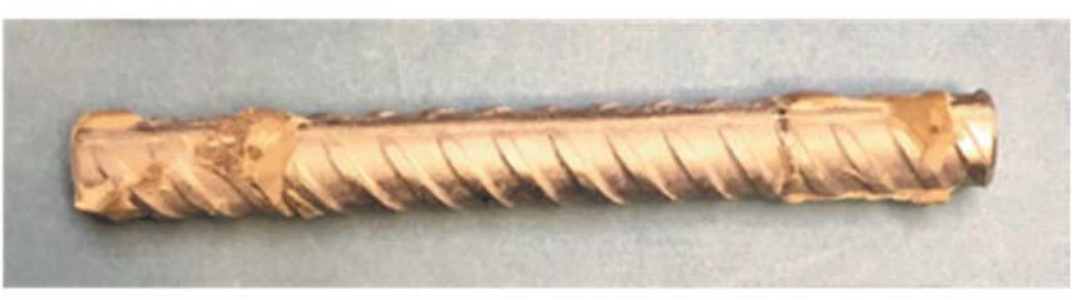

FIG. 9 Visual observation of carbon steel bar $(A)$ and stainless steel bar of grade 304L (B) embedded in alkaline concrete made with seawater at the end of the exposure cycles.

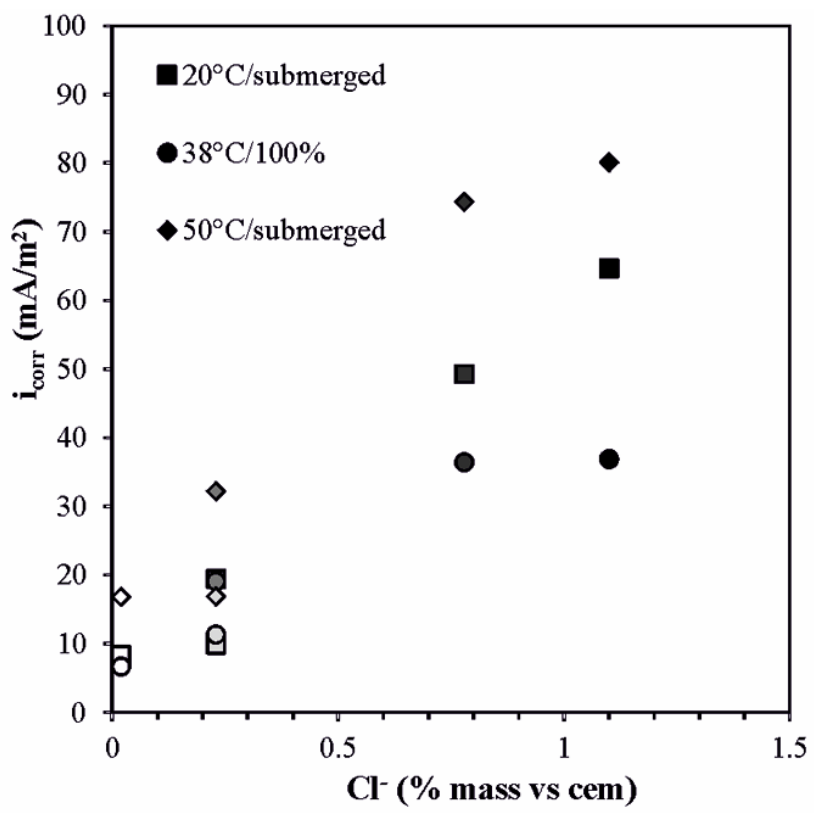

FIG. 10 Corrosion current density as a function of the expected chloride content of the different types of concrete and the exposure conditions. Fill symbol indicates the type of concrete (increasing the darkness, the expected chlorides amount increases). 

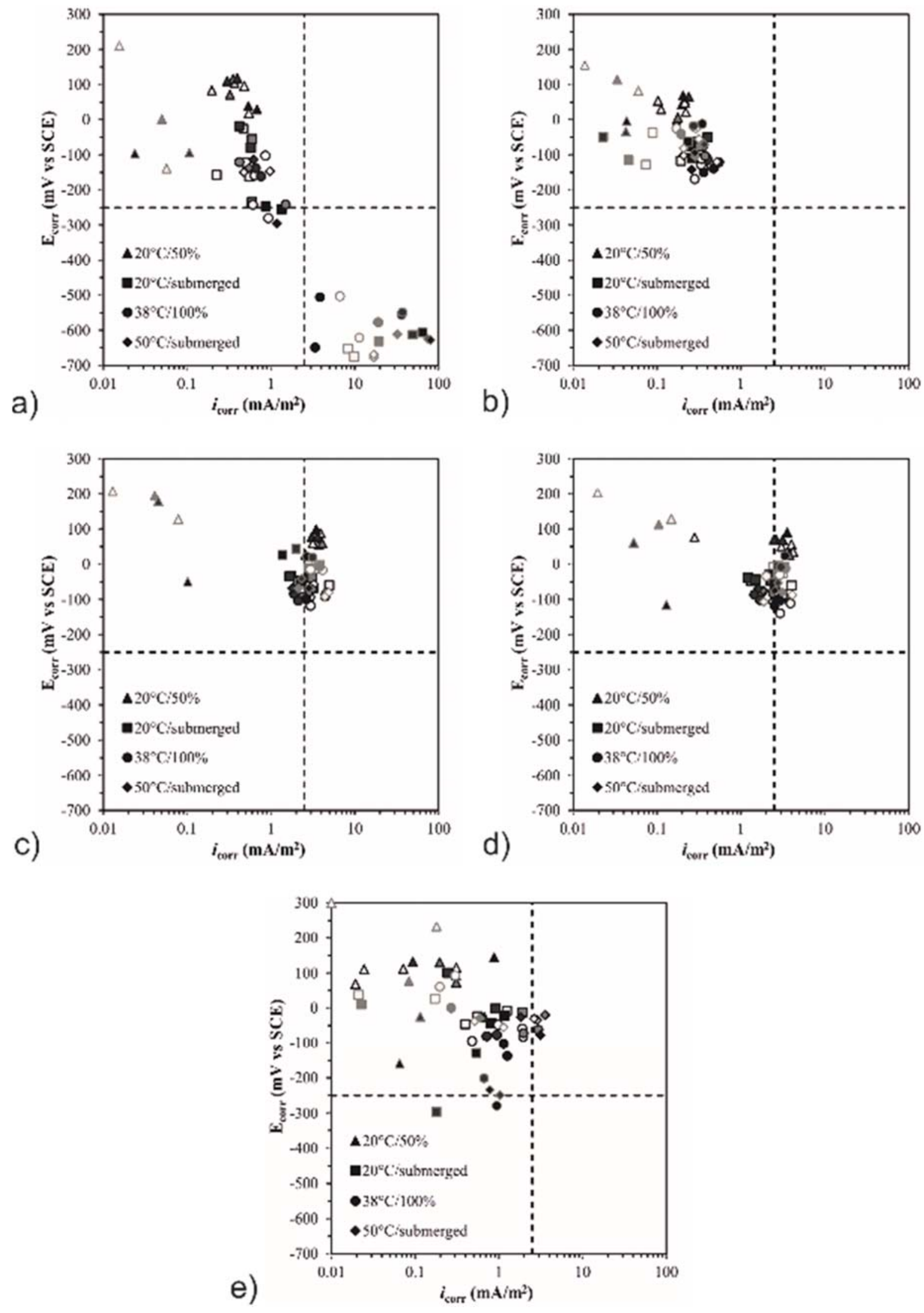

Page 30 of 31 
FIG. 11 Relationship between corrosion current density and corrosion potential as a function of the type of concrete, the exposure conditions and the different types of bars: carbon steel (A); 304L (B); 22-05 (C); 23-04 (D); XM-28 (E). Fill symbol indicates the type of concrete (increasing the darkness, the expected chlorides amount increases); black border symbol = alkaline concrete; grey border symbol = carbonated concrete . 